\title{
Spanish media in a new digital world: The great bonfire of the vanities
}

\section{Los medios españoles ante el nuevo mundo digital: La gran hoguera de las vanidades}

\author{
José María Álvarez-Monzoncillo \\ Professor of Communication Studies \\ (Universidad Rey Juan Carlos) \\ Guillermo de Haro Rodríguez \\ Associate Professor of Applied Economics \\ (Universidad Rey Juan Carlos) \\ Javier López-Villanueva \\ Associate Professor of Communication Studies \\ (Universidad Rey Juan Carlos) \\ - Guest paper -
}

Reception date: 25 de julio de 2016

To cite this article: Álvarez-Monzoncillo, J. M., de Haro Rodríguez, G. y López-Villanueva, J. (2016): Spanish media in a new digital world: The great bonfire of the vanities, Icono 14, volumen 14 (2), pp. 9-45. doi: 10.7195/ri14.v14i2.998 
10 | José María Álvarez-Monzoncillo, Guillermo de Haro Rodríguez y Javier López-Villanueva MONOGRÁFICO

\section{Abstract}

The mass media in Spain has carried out major adjustments in recent years in order to adapt to the Great Recession and to disruptive or ground-breaking technology such as Internet. This has underpinned the drop in advertising revenues and government subsidies, as well as a decline in sales and subscriptions. In the boom years, promises of Internet and easy access to global financial markets at interest rates below inflation encouraged media groups to design vertical and horizontal expansion strategies aimed at positioning themselves in the domestic market whilst expanding overseas: particularly in Latam and Europe. Moreover, consumers have been able to access contents more easily and cheaply via the Internet and using a broad range of devices. The poor economic situation of traditional media (caused, mainly, by their high financial gearing) prevents them from successfully facing new challenges requiring them to change whilst new digital companies are managing to get by in spite of the highly precarious economic scenario.

\section{Key Words:}

Global value chains- Digital disruption - Media evolution - Media industries - Spain

\section{Resumen}

Los medios de comunicación de masas en España han realizado un ajuste importante en los últimos años para adaptarse a la Gran Recesión y a una tecnología disruptiva como ha sido, en muchos casos, Internet. Esto se ha traducido en la caída de los ingresos publicitarios y de las subvenciones públicas, más una bajada de ventas y suscripciones. En los años de bonanza, las promesas de Internet y el fácil acceso a los mercados financieros internacionales a intereses bajos por debajo de la inflación hicieron posible que los grupos diseñaran estrategias de expansión verticales y horizontales para tomar posición en el mercado nacional y expandirse hacia los mercados internacionales, fundamentalmente hacia América Latina y Europa. Además, los consumidores han podido acceder más fácilmente y a un menor precio a los contenidos a través de la red y con multitud de dispositivos. La mala situación económica de los medios clásicos (provocada, sobre todo, por su alto endeudamiento) no permite afrontar los nuevos retos que exige el cambio mientras que las nuevas empresas digitales subsisten bajo una elevada precariedad económica.

\section{Palabras clave:}

Cadenas de valor global - Disrupción digital - España - Evolución de los medios Industrias de la comunicación 


\section{Introduction}

Five centuries ago, a Dominican friar called Girolamo Savonarola persuaded a group of his followers to build a huge bonfire in the centre of Florence with Renaissance books, works of art, objects and new technologies that they considered to be sinful. Later, they set fire to it in protest against the new global order. His so-called "bonfire of the vanities" aimed to halt the evolution of an era in which business was transforming medieval societies; a rich merchant class was beginning to arise; major migratory flows were under way; and new technologies, such as the printing press, were beginning to thrive (Goldin and Kutarna, 2016).

However, economic growth and numerous innovations led to major imbalances. For example, as different regions were interconnected breakages in established supply chains began to appear, unqualified workers were driven out of new labour markets, and economic inequalities increased (Goldin and Kutarna, 2016). There were also technological breakdowns: such as the case of the printing press which changed the value chain of editing whilst turning what was previously a luxury good into a commodity and allowing for much more efficient distribution of contents.

For the last forty years we have been witnessing another transformation process whereby the industrial map has suffered major reconfigurations - both qualitative and quantitative - of traditional methods of production, distribution and consumption (Dicken, 2011). Direct foreign investment, outsourcing, offshoring and cross-border trade have increased substantially during this period. All of the above was also propelled by the increase in industrial capacities of developing countries, improvement of their institutions, and lower transportation costs; end of the cold war and the rise of market systems; and lower import tariffs and new ICT (Information and Communication Technologies) allowing for integration of distant activities. Thus, we face the dichotomy of a world that is becoming smaller and smaller thanks to the connection of territories which used to be far apart but at the same time getting bigger and bigger given the expansion of trade horizons (0sterhammel \& Petersson, 2013).

The media is in the epicentre of this huge mutation. Internet, social networks, the continuous improvement of technologies, the hacker revolution and global 
markets have granted new powers to consumers. Moreover, the Great Recession must be added to the wave of changes taking place. The scenario under which contents are created, chosen, presented, aggregated, distributed and consumed has been transformed. The media's roles and financing have also been mutating (Heinonen \& Luostarinen, 2008), together with their former sender-receiver relationship and gatekeeper role (Bruns, 2005).

Thanks to those driving forces, media industries have been forced - gradually - to cut and reposition supply and distribution chains, which has led to more fragmented and disperse industrial activities from a geographic point of view but more integrated from an economic point of view. Thus, the division of labour has taken on a new dimension as a greater number of activities in different locations under complex connections have been disaggregated. For many workers this can cause substantial job insecurity.

With hindsight, it looks like traditional Spanish media weren't completely reactive to changes that were taking place. The main difficulty was to come up with a creative strategic system and, simultaneously, follow an established strategic path (Rothmann \& Koch, 2014). For private sector media, this became more pronounced when their room for manoeuvre was hampered by the economic crisis due to high financial gearing racked up during good times. Thus, in 2012 their debt peaked at around €6.6Bn (García-Santamaría, 2016). This led to massive lay-offs, M\&A deals, shutdowns and bankruptcies. Public radio and television groups suffered similar processes as, due to high public debt loads and deficit reduction targets, their subsidies were cut drastically.

At heart, we are witnessing an accumulation of vanities. Traditional media hoped that changes would be temporary and everything would go back to normal. Media industries have repeatedly tried to suppress the radical potential of new technologies in an effort to prevent them from disrupting established global value chains (Winston, 1998). Their vanity underpinned an excessive delay in necessary changes. New media arising out of the heat of Internet have intended to begin from a blank slate (vs. the status quo), often without being aware that they were acting like alchemists yearning to convert copper into gold. Consumers, with a 
level of selfishness and narcissism which seems never-ending (Twenge \& Campbell, 2009), aim to consume contents from multiple devices to their hearts' desire and free of charge. Yet, the main problem for some media is that they don't control the new platforms: some, therefore, are seeing their classic value chains destabilised and others are finding that there aren't any sustainable business models in the new world. In this great bonfire of the vanities, the old hasn't been completely killed off and the new hasn't finished being born. For the time being, the media ecosystem continues to burn under a scenario of destabilisation.

This research aims to analyse industrial changes that have taken place in the Spanish media sector in recent years. Firstly, we set forth the theoretical framework for economic analysis that we have used. Later, we apply it to the press, television and radio. Finally, we study the outlook for Internet and the expected future of the media sector as a whole.

\section{Value chains and economic characteristics of the media}

Our sector research is underpinned by a global value chains (GVC) perspective and the basic economic characteristics of the media. Using a GVC we aim to explain how the sector is organised and anticipate future trends. Through the metaphor of a chain with different links we can analyse the social and economic organisation surrounding the life of a good or service from its conception until it is consumed by the final user and eliminated or recycled after its usage. It is a heuristic tool that has been under development since the end of the last century and that recognises that the life cycle of any good or service follows a series of subtle and linked economic activities (Kaplinsky, 2013). If we trace its genealogy, we see that it is based, primarily, on the world-system theory (i.e. Hopkins and Wallerstein, 1986), the French "filière" analysis (refer to summary in Morvan, 1991) as well as strategic administration research (such as Kogut, 1984 or Porter, 1985).

The image of a chain might seem simplistic, but it provides us with a systematic roadmap for carrying out and structuring our research and allows us to organise 
the necessary political answers (Sturgeon, 2008). It is mainly useful for understanding an industrial event as a constellation of closely linked steps, in order to avoid focusing only on final goods or production, which is a weakness of a lot of sector research. Moreover, this is intermeshed with industrial changes taking place during the past few decades.

GVC modelling allows us to study four of the sector's main elements: its input-output process, where the main processes needed to transform inputs into final products are described; the geographic configuration or territoriality; the governance structure, which refers to the processes whereby certain components of the chain exercise power over others and appropriate or distribute the value that is created along the links; and its institutional framework, that establishes the "rules of the game" under which organisations act and the chain is operated (Gereffi, 1994: 97).

A chain is embedded in exogenous institutions (i.e. civil society or general laws), under universal technologies, in a certain geographical location and has the support of auxiliary industries. Moreover, industrial niches attempt to penetrate into them (Geels, 2014). As if they were Russian dolls, three interrelated forms of embeddedness evolve simultaneously (along the lines of Granovetter, 1985): industrial, socio-technical and territorial. All of these embeddedness influence each other.

In each node of the chain there are certain given economic characteristics. From the point of view of the neoclassic economy, the media produces goods based on information and talent (Dolfsma \& Nahuis, 2006; Caves, 2000). Thus, at the beginning of the chain contents created (contents are understood to be everything exchanged that is not necessary for maintenance of the networks) have a specific costs structure: the creation of a prototype has high fixed costs, but reproduction costs are practically nil. If the project fails, which is often the case, costs become sunken and cannot be recovered. In other words, high investment costs before a product can be advertised imply that companies must take substantial risks.

The media tends to create on-going products via coordinated and structured processes (Picard, 2005). It's not only about creation as selection, processing and packaging are also taking place. They are playing with various nodes of the chain 
at the same time. Therefore, a change in any one of them immediately affects the whole chain. Furthermore, as they are generating regular usage, they must pay attention to their brand names.

Technology has allowed entry costs to decline (youtubers are an example) whilst those of creation or innovation of processes have trended upwards. Paradoxically, the most efficient companies have used new technologies to raise costs. With this "race of quality" (Bakker, 2005: 311) they manage to differentiate themselves from and leave behind their competitors.

When it comes to distribution, goods based on information tend to be public goods (Adams \& McCormick, 1993). On the one hand, this is because their consumption by a person does not by any means reduce that of others. Moreover, thanks to technologies, contents may be consumed at the same time by numerous individuals without affecting quality. On the other hand, this is because it is difficult (increasingly so with Internet) to exclude those who want to consume for free bypassing intellectual property rights. In the digital world copies can't be distinguished from originals and distribution barriers are minimised. This stems from innovations that improve the transmission of large quantities of data (such as fibre optic or satellites), devices that gather, store or recover information and services that provide interfaces. In short, contents - in the distribution phase - tend to be non-rivals and non-excludable, which is a problem for their amortisation.

As marginal costs of reproduction tend towards zero, from an economic point of view establishing a positive price is inefficient as the marginal cost is not equal to the marginal price. Yet, if the cost of a content was zero nobody would produce it or there would be infra-production.

In order to solve this, and given difficulties in excluding those who are unwilling to pay, at the exhibition level platforms tend to be multisided (Evans \& Schmalensee, 2016). This allows for different types of media consumers to be complementary. For example, free-to-air TV can bring spectators together with advertisers and, thanks to the latter, the former can access the product for free. For advertisers contents are, therefore, a private good (rival and excludable). 
Internet has allowed for the creation of multiple platforms without borders that reduce transaction costs. This increases the pressure on those companies that opt to charge their clients.

There is also the possibility of establishing price discrimination: charging consumers one price or another based on their willingness to pay. This allows distributors to move all along the demand curve and cover the possibilities or needs of different consumers. Thus, some consumers will pay a higher price, but more people can consume the contents. This discrimination is more effective in the case of more durable goods (a TV series) than in that of rapidly consumed goods (the news). Moreover, price discrimination tends to be combined with product differentiation and pure bundling. For example, a physical magazine can have a small or large format and be sold as a whole.

Payment media solve the problem of excludability, but not that of rivalry and piracy. The days in which there only existed one point of entry to a media are behind us and now users can gain access from any connected location. Since digital contents can be reproduced or adapted, and usage or copying don't cause them to deteriorate, personalisation should tend to rise.

The main problem is that these unique characteristics of the media are increasingly not applicable online as information goods are losing their links with physical goods. Thus, the press is losing its character of pure bundling, multisided platforms are observing that many consumers now do so on demand in order to avoid advertising, and price discrimination is becoming more complicated. In the following sections, we analyse how all of the above is breaking or tightening the global value chains of the press, television and the radio.

\section{The press and its unfinished conversion}

Until the early years of the 21st century the press was a stable industry capable of maintaining substantial economic profits (Picard, 2008). Moreover, economic growth led to profitability improvements year after year as there was a close correlation with advertising spending in the press. Publishers achieved double digit margins, much 
greater than those of other industries (OECD, 2010). Thus, for example, in Spain sector profits rose from €100Mn to €233Mn between 2001 and 2007.

The traditional press had a simple lineal global value chain (GVC) whose fundamental segments were the creation of contents, aggregation, production, distribution and consumption. The Great Recession made apparent a series of destabilisations that had been emerging in the last links of the chain: a steady decline in consumption of newspapers, their circulation and their advertising revenues. The effects of the arrival of Internet (mainly digitalisation and compression mechanisms), together with a series of social changes and the possibility of consumption without borders, began to be fully apparent in the industry. Given the bidirectional union between all of the nodes, the crisis ended up affecting the creation of contents. At the end of the day, the three embeddedness of the chain (industrial, socio-technical and territorial) suffered mutations at the same time. This is why the sector crisis has been so acute.

Classic newspaper publishing is characterised by high sunk costs (printing presses, paper and workers) and low marginal costs of reproduction and distribution. As a result, barriers to entry are very high. It may seem obvious but it is worth stressing that newspapers have always produced readers, not news, as their primary goal (Conboy \& Steel, 2008). In fact, they sell news to readers and readers to advertisers, using a multisided platform. When there are no revenues flows from earning nodes (mainly advertising and sales) producing segments end up in a precarious situation.

Thus, while in 2001 there were 136 different Spanish newspapers published, in 2015 only 106 remained (AEDE, 2015). Since the Great Recession we calculate that nearly 2,900 workers have lost their jobs with printed newspapers or a drop of approximately - $50 \%$ vs. the former sector workforce. Moreover, the average base salary of journalists included in the collective bargaining agreement dropped by -17\% between 2010 and 2015: from a gross annual salary of $€ 32,532$ to $€ 26,972$ (APM, 2015). 0ther mechanisms for controlling expenditures have been the closure of correspondent offices, the reduction of pages and a trend towards cheaper news or comments. All of these moves end up deteriorating the attractiveness of the product for the consumer.

DOI: ri14.v14i2.998 | ISSN: 1697-8293 | Año 2016 Volumen 14 Nº 2 | ICONO14 
18 | José María Álvarez-Monzoncillo, Guillermo de Haro Rodríguez y Javier López-Villanueva MONOGRÁFICO

Many of these laid-off workers have been involved in start-ups of on-line media: with 458 still active at the end of 2015 (APM, 2015). Of these, there are 112 exclusively digital newspapers (AEDE, 2015). The barriers to entry in these cases are lower, as costs can be $-80 \%$ less than those of their paper peers. The latter are now faced with numerous new corporate competitors but also with social networks and a slew of solitary self-creators. Traditional players have ended up going online as well, although for the time being they must bear both physical distribution and online costs.

Throughout their history newspapers have benefitted from multiple new technologies such as photography, word processors, design software, improved transportation networks, and colour printing. All of these innovations were inserted without any problems in the various links and made them more efficient. However, the arrival of Internet doesn't follow this script mainly as all pure bundlings have been broken down (e.g. newspapers) and become mixed (consumers only consume the news that interests them); advertising is transferred to other specialised platforms (for example advertisements for flats are transferred to specialised websites such as idealista.com); and private goods tend to be converted into public goods.

From an economic point of view pure bundling tend to be preferable for sellers than mixed ones. A price is charged for a set of grouped products (e.g. different sections of a newspaper) that may not be of equal interest to the consumer. When Internet allows for this bundling to be broken up (debundling), the main problem is that it ends up affecting the two key sources of revenues: advertising and sales.

As we have pointed out, newspapers have acted like multisided platforms that unite readers and advertisers. Advertising should allow the price of the product to decline (or even allow it to be free) which, at the same time, should allow the number of readers to increase in a positive feedback cycle. All of the traditional newspapers have created websites, applications and blogs but they have not managed to transfer printed advertising to the Internet. In fact, in recent years advertising spending in Spanish newspapers has fallen to nearly one-third (its former level) although it looks like a floor has been reached (refer to Table 1): from $€ 1,894 \mathrm{Mn}$ in 2007 to around €659Mn in 2015 (Infoadex, 2016). 
This was primarily underpinned by three factors. Firstly, part of its advertising has migrated towards other specialised platforms (e.g. housing or job offers) where it is more efficient for buyers and sellers to meet. Secondly, advertisers have developed applications in order to contact their clients directly. Finally, prices paid for online advertising are very low since there is no longer a shortage of advertising space, the response rate is very low and advertisers don't have reliable measurement systems. Moreover, a large portion of online advertising (which amounted to nearly $€ 1,250 \mathrm{Mn}$ in Spain in 2015) is shifting towards new platforms such as Google or Facebook which also act as news aggregators. However, the World Federation of Advertisers estimates that between 10 and 30 per cent of online advertising slots are never seen by consumers because of fraud (WFA, 2016).

\begin{tabular}{|c|c|c|c|c|c|c|}
\hline & 2001 & 2008 & 2012 & 2013 & 2014 & 2015 \\
\hline Newspapers published & 136 & 139 & 113 & 110 & 106 & 106 \\
\hline Readers (millions) & 16.2 & 20.3 & 20.1 & 18.6 & 17.3 & 15.7 \\
\hline Circulation (millions) & 3.89 & 3.96 & 2.88 & 2.45 & 2.26 & 2.21 \\
\hline Rotation rate & 4.2 & 5.1 & 7 & 7.6 & 7.6 & 7.1 \\
\hline Advertising spending (€ millions) & 1.594 & 1.507 & 766 & 662 & 656 & 658 \\
\hline Penetration (\% population) & 35.9 & 42.1 & 36.1 & 32.4 & 29.8 & 28.5 \\
\hline Daily consumption (minutes) & 15 & 17.7 & 13.8 & 12.3 & 11 & 10.5 \\
\hline Profits (€ millions) & 100 & 11.9 & -123 & -23 & -1.6 & na \\
\hline
\end{tabular}

Table 1: Main press data trends in Spain (2001/15)

Source: In-house preparation using data of AEDE, AIMC, EGM and Infoadex.

Product sales have suffered substantial changes due to Internet. Until now, the four main online business models that have been established don't appear to be generating sufficient funds (Goyanes, 2014): the free model (free access offset by advertising); the pay model (payment via subscriptions or unit sales); "freemium" 
(some contents are free and others must be paid for); and the metered model (free access up to a certain number of articles and payment later required).

The first model assumes that readers can access a lot of free information online so that they have the possibility of consuming cost-free the same contents that are offered in a paid newspaper (Casero-Ripollés, 2010). In other words, the private good of a paper newspaper (excludable and rival) gives way to a public good on the Internet (non-excludable and non-rival). However, as we have seen, advertising (private good) is insufficient to offset this gratuity online.

Empirical data seem to demonstrate that readers are unwilling to pay for information, which they see as a mere commodity since they have become accustomed to online gratuity (Goyanes, 2012). As a result, the pay and freemium models don't work. In fact, when payment systems are installed visits and advertising nosedive. Finally, it looks like news meters are only going to work for very high-quality global newspapers (such as the Financial Times or New York Times), but not for the rest. In Spain it looks like none of these models is working satisfactorily. Some authors (such as García-Santamaría, Pérez-Serrano \& Maestro-Espínola, 2016) have pointed to reader or subscriber clubs as a successful strategy. Yet, it seems like with the products or services that they offer it will be difficult for newspapers to achieve better prices for their subscribers than those achieved by large websites such as amazon.es. Due to their minimal size we foresee, in principle, neither economies of scale nor scope.

In short, the dilemma consists of not managing to structure a collective good online (excludable and non-rival). Yet, to achieve a minimum level of sector profitability it will be necessary to establish some form of payment (Graybeal \& Hayes 2011). The curious thing about the Internet is that for traditional newspapers it is both a rival and the media that will allow their survival.

The consumption node in Spain has also become more precarious in recent years: traditional newspapers' 20Mn readers in 2008 declined to 16Mn in 2015 and they only spend around 10 minutes reading the paper a day (refer to Table 1). Visits to webpages of the press have increased to an average of 700,000 unique 
visitors in 2015 (AEDE 2015). However, this media has a high standard deviation as half of the websites have less than 100,000 unique visitors and the top 20 players comprise $85 \%$ of visitors.

Circulation has been nearly halved, from 2.4Mn units in 2015, which implies high rotation and an index of circulation per 1,000 inhabitants of 51 (refer to Table 1). Only in the year 2001 did it surpass the cut-off level of 100 units that the UNESCO defines as necessary in order to consider a country developed from a cultural point of view. Moreover, there is a noticeable geographic gap as $70 \%$ of newspapers are purchased in the North of Spain.

The loss of credibility of newspapers and journalism also underpins this trend (Meyer, 2009; Díaz-Nosty, 2013). It doesn't seem like Spanish readers place much value on pure bundling nor on news that are more expensive to produce. As we have already pointed out, in a pure bundling system the reader had to pay for everything in order to get what she wanted. This allowed newspapers to spread out costs and create a global product. In the end, readers received more than what they asked for. However, if they only want the typical news viewed the most frequently on the Internet (normally lifestyle and sports) they cannot have the rest as this breaks of mechanism of crossed financing of the news. Meanwhile, this also ends up affecting the quality of most popular news. Elements such as access to information; misinformation or journalistic ethics must not be taken lightly (Díaz-Nosty, 2011).

Nevertheless, readers continue to opt for values linked to the printed press such as objectivity, credibility, honesty or depth, although at the same time beginning to choose aspects such as speed and accessibility, where the digital press is beginning to take the reins (AEDE, 2015). For the time being, many of the pure newspapers proposals online are faced with major limitations in terms of budgets and journalist quality.

Changes are moving towards an industry that is certain to be less interesting for those investors seeking high returns. In fact, the sector's P\&L accounts have fallen from earnings of €233Mn in 2007 to losses of $-€ 123 \mathrm{Mn}$ in 2013 (refer to Table 1). Cuts in recent years seem to have halted the blood bath of losses but the industry still hasn't managed to come up with a viable economic model. 


\section{Television's smooth evolution}

Since public broadcasting's beginnings, television has been in a permanent process of evolution. For example, broadcasting via electromagnetic waves was followed by cable, satellites, and DTT; the cathode tube gave way to the plasma flat screen; the transistor was replaced with the chip; black and white was overcome by colour; and blurred images gave way to high definition in 3D. In addition, it was even able to emigrate quite easily to Internet and has become mobile. Moreover, a television of scarcity that reached the mass has given way to one of abundance and niches in which the programmer has less and less power whilst the viewer can structure a personal collage comprised of his/her favourite programmes (López-Villanueva, 2011).

Television has survived technological transformations, regulatory changes and new forms of relationships between TV programmes and viewers (Uricchio, 2009). In fact, during its first 50 years of life television maintained its basic industrial practices. It has probably been the media that has suffered the greatest number of transformations but has managed, thanks to its huge opportunism, to adapt to all of them.

During the last decade numerous factors have underpinned a new evolution of television: technology has fostered a dramatic improvement in conditional access, time-shifting, ubiquity and mobility; the relationship with its geographic space is changing; its public is segmenting; channels are continuously multiplying; access to advertising is becoming more complicated; and numerous new amateur production/distribution agents are springing up. Moreover, in television, three industries are beginning to converge - audiovisual, telecommunications and IT -, each with a very different history and economic weight. Changes taking place are so monumental that they are straining the classic value chains, to the point that some authors are already talking about the death of television (Missika, 2006) or its "Spotifyization" when converted into just one more Internet application (Wolk, 2015).

Yet, data don't seem to be backing up these scenarios. Some TV viewers may stop watching their TV set but not television, which is still a core part of their leisure activities. Moreover, the vast majority of successful channels are lineal: they are watched live and use offline technologies. History seems to indicate that in the television sector new value chains enter, successively, and end up coexisting in a pleasant way. 
The three large television models that coexist in Spain (free-to-air public television; free-to-air private television; and pay-TV) have different sources of revenues, technologies and institutional frameworks. On the supply side, they tend to be more complementary than substitute products. They all have very similar costs structures: high sunk costs (nearly $80 \%$ of programmes launched in Spain end up failing); almost nil marginal costs of reaching an additional viewer; moderate distribution costs (in 2015 television groups paid nearly €350Mn for transportation and diffusion of signals); and high fixed production costs.

As illustrated in Figure 1, between 2008 and 2015 investments in audiovisual production of television stations as a whole declined from €474Mn to €328Mn, implying a drop of $-30.8 \%$ (Álvarez-Monzoncillo, Baraybar \& López-Villanueva, 2015). This stems from lower revenues from advertising, subsidies and subscriptions as a result of the Great Recession.

Those investments don't take into account the cost of news programmes, sports rights and acquisitions of foreign production. In other words, these figures only consider two categories: fiction (series, films and TV-movies) and other programmes (such as reality, game and talk shows). In the Spanish market only a dozen production companies are continuously producing and are capable of taking on all types of projects.

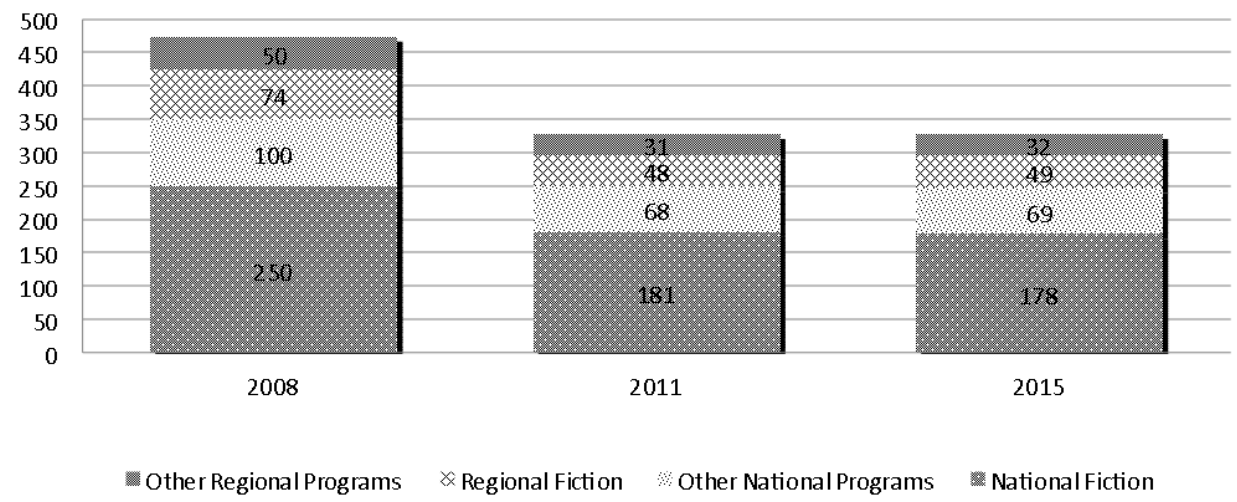

Figure 1: Audiovisual production investment trends in Spain (2008/15) -In millions of eurosSource: Álvarez-Monzoncillo et al 2015 
Free-to-air private television is structured like a multisided platform that brings together TV viewers and advertisers. For the former it is a public good and for the latter it is a private good. Since the latter makes television possible, the platform should maximise audiences. Under a positive feedback model, more successful channels will attract the most advertising spending as they have more viewers with the target profiles that advertisers are seeking and, therefore, more revenues per viewer. The television channel continues to occupy a prevalent position with respect to other platforms, thanks to its enhanced brand identity and premium products (Guerrero, Diego \& Pardo, 2013).

In Spain two groups (Mediaset and Antena 3) control close to $90 \%$ of TV advertising spending. The market has evolved from a public monopoly in the mid-1980s towards the present duopoly. Although there is more competition nowadays than in the early 1990s, the industry can be considered to be in the limit between moderate and high concentration levels (Artero \& Sánchez Tabernero, 2015).

A duopoly has been created since advertising cannot reach other channels. Firstly, this reflects the fact that advertisers will always pay more to reach a new audience than to reach that same audience for a second time via a minority channel. Secondly, this is because the advertising market doesn't have the capacity to grow in tandem with the number of channels and remains closely linked to economic cycles.

Versus the press, advertising has neither abandoned free-to-air television nor migrated towards Internet given that large brands need the masses and because television viewing has increased. Brands are dependent on multiple occasional buyers: those with long gaps between purchases and who buy competing brands in between. Therefore, they can never increase their market share by targeting existing users, something that is done quite well by online advertising (Sharp, 2010). What they need to do is to get the attention of non-interested people, who never consume their product or did it so long ago that they don't even remember (Sharp, 2010). The only advertising that can achieve all of that is TV advertising, which has returned to a positive growth trend since 2013 (refer to Table 2). 
The Government deficit and debt burden have underpinned a drop in subsidies granted to public channels. This has led to a balancing out of revenues generated by advertising, payments and subsidies at around $€ 1,800 \mathrm{Mn}$. However, using Data Envelopment Analysis (DEA) method and benchmarking more than a half of regional public television services in Spain are inefficient (Artero, Orive \& Latorre, 2015). To ensure their future sustainability they should change their governance.

\begin{tabular}{|c|c|c|c|c|c|c|}
\hline & 2001 & 2008 & 2012 & 2013 & 2014 & 2015 \\
\hline Free-TV revenues (€ millions) & 2,162 & 2,998 & 1,665 & 1,580 & 1,713 & 1,798 \\
\hline Pay-TV revenues (€ millions) & 1,387 & 2,090 & 1,747 & 1,715 & 1,742 & 2,067 \\
\hline Subsidies public TVs (€ millions) & 1,154 & 1,178 & 2,025 & 1,859 & 1,669 & 1,610 \\
\hline Advertising spending (€ millions) & 2,151 & 3,082 & 1,815 & 1,703 & 1,890 & 2,011 \\
\hline Pay-TV subscribers (millions) & 3.5 & 4.6 & 4.2 & 3.9 & 5.1 & 5.5 \\
\hline Lineal TV daily consumption (minutes) & 208 & 227 & 246 & 244 & 239 & 234 \\
\hline Online TV daily consumption (minutes) & - & - & - & - & 8 & 10 \\
\hline Connected Smart TVs (\% households) & - & - & - & 4.3 & 6.6 & 7.8 \\
\hline Pay-TV subscriptions (\% households) & 21.4 & 24.7 & 21.6 & 18.8 & 20.6 & 24.8 \\
\hline
\end{tabular}

Table 2: Main television data trends in Spain (2001/15)

Source: In-house preparation with data of AIMC, CNMC, Infoadex, Kantar Media and Videometrix

The most noteworthy difference between channels dependent on advertising and those of pay-TV is that in the latter case the price mechanism can play a role: prices convey information regarding valuations of consumers, which leads to more efficient allocation of products (Van Dijk, Nahuis \& Waagmeester, 2006) and a significant increase in the supply of channels; pay-TV creates a market with prices, bundlings and subscriptions. Moreover, channels can also resort to financing themselves via advertising. 
Contents tend to be sold in pure bundlings associated with other services under mixed bundlings. The consumer has some choice but may end up paying for much more than she wants. Numbers of bundlings available and of pay-TV subscribers have increased in parallel. In 2015 there were 5.5 million pay-TV subscribers in Spain: half of them subscribed to a "quintuple-play" deal marketing together telephone, fixed, broadband, and mobile services with pay-TV.

The pay-TV market is also very concentrated due to the high costs of acquisition of premium contents (mainly football and Hollywood fiction) and to economies of scale achieved in purchasing, distribution and marketing. Movistar and Vodafone account for $85 \%$ of total pay-TV subscribers in Spain.

Conditional access technologies are essential for excluding those consumers who fail to pay. In other words, pay-TV is configured like a collective good (non-rival and excludable) where subscription revenues must be maximised whilst offering consumer satisfaction.

Another form of pay-TV allows for online consumption. The most noteworthy players in Spain in this segment are the 0ver-The-Top (OTT) providers Netflix and Wuaki. At the end of the day, what they have done is to move pay-TV narrowcasting to the Internet. It is not a service generated by users and is neither social nor free. It is like traditional pay-TV, but with online distribution for those who want to pay less.

It is structured like second level price discrimination based on the lower quality of contents. As a result, OTT services don't fit too badly into the three TV models. In fact, they are an interesting secondary market for many operators. However, if we add up the annual revenues of all of OTT offers in Spain (around €8Mn in 2015) they would probably be less than the advertising revenues generated by a Spanish football league "el clásico" match. It doesn't look like these Internet channels are able to pay up the huge economic sums needed to purchase rights to broadcast major sports and/or Hollywood movies.

Low subscription rates of OTT services cannot be blamed on deficient infrastructures. In fact, Spain is the European country with the greatest number of 
subscriptions to fibre optic Internet access (around 25\% of lines have connection speeds of over 30Mbps) and has one of the highest levels of usage of Smartphones to access the Internet (almost 90\% used that device in 2015). Moreover, nearly $80 \%$ of households have $4 \mathrm{G}$ coverage (Telefónica, 2016).

Lineal TV consumption has declined over the past several years to 234 minutes per day in 2015. Yet, this figure is still the 4th largest level of TV consumption registered since this data has been available in Spain. The daily average of minutes has a high standard deviation: those less than 24 years old consume around 133 minutes while those over 75 reach 251 minutes (MECD, 2016). Cross media audience measurement is underdeveloped in Spain (Quintas-Froufe \& González Neira, 2016), but, according to data, online TV amounts to ten minutes per day and time-shift viewing only amounts to three minutes. Thus, viewing total in all forms is 247 minutes per day. Therefore, for the time being, it looks like television is enjoying a relatively smooth development within the digital world.

\section{Radio uncertainties: Between radio waves and bits}

The radio industry is still holding up in spite of hardships posed by other leisure and information activities related to development of the Internet: $60.4 \%$ of the Spanish population listens to an average of 105 minutes per day. ${ }^{1}$ Contrary to the situations of television and the press, young people listen to the radio: more than a quarter of radio audiences are less than 34 years old. This consumption is greater in the case of thematic radio channels than in that of general interest stations ( $55 \%$ vs. $48 \%$ ). Moreover, the expected trend in upcoming years is a progressive increase in access via different devices and platforms; i.e. nomad, à la carte and on-demand broadcasts.

In spite of all of the M\&A deals linked to multimedia diversification and strategies for confronting the Internet, there is high competition among radio operators. However, the increasing concentration that has taken place in the sector as a whole in recent decades is an undeniable fact. Figure 2 illustrates the audiences of the main operators in the Spanish market. 


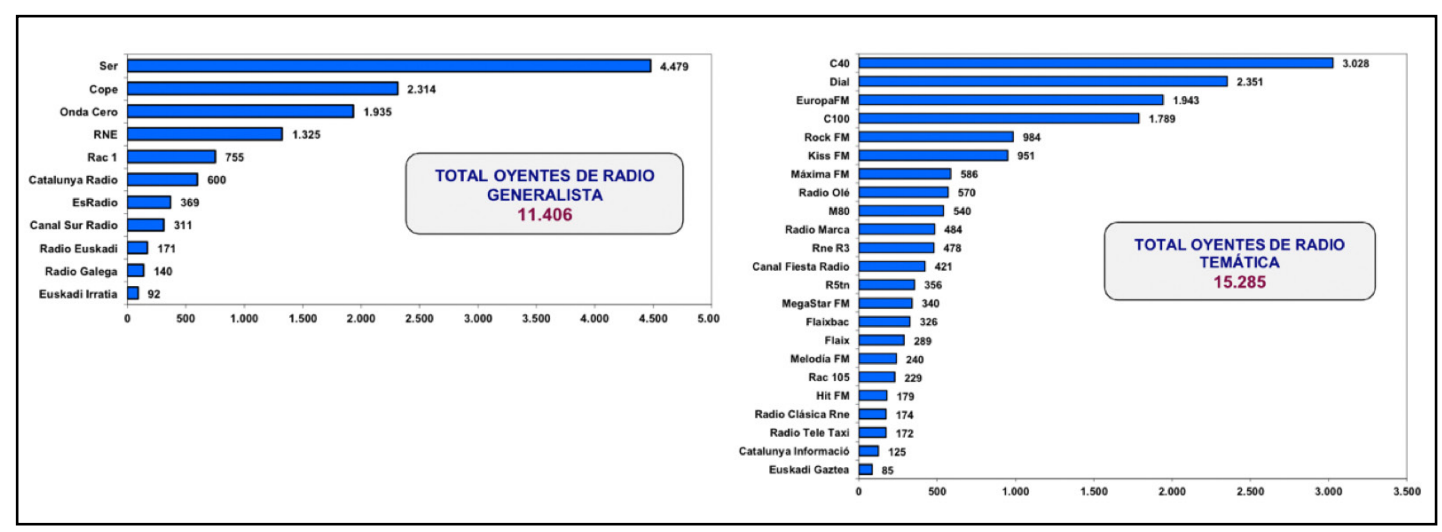

Figure 2: Daily radio audiences in millions of people (2016)

\section{Source: $E G M$}

The radio in Spain is dominated by three private groups, relegating public operators to the back seat. The private sector "appears to be fragmented into hundreds of local frequencies organised into chains with their three main markets - stations, advertising and audiences - highly concentrated, integrated into multimedia groups and oligopolised by a handful of operators with strong political alignments" (Badillo \& Pérez 2012: 96).

Public radio, associated with national and regional public television entities, has been at the mercy of financing of public radio and television services in its spheres of activity: nationwide, regional and local. It has an uncertain future with the new configuration of digital licenses since more channels and "new" audiences must be serviced with declining budgets.

The configuration of the market goes hand-in-hand with policies of granting licenses implemented in the recent years and readjustments underpinned by increasing competition on the back of declining advertising revenues. The disappearance of public radio stations stems from a decrease in public funding, their minimal agility to adapt to changes and a certain lack of flexibility for achieving on-going programming improvements. The historic public-private status quo of the radio sector has recently been disturbed and it looks like the process of digitalisation of the sector and growth of Internet audiences is likely to weaken the public sector even further. 
The main characteristics that define the Spanish radio sector are as follows: a high level of concentration, saturation of the radio spectrum, stagnation of audiences and a digital radio segment that hasn't yet managed to take off (García-Santamaría, 2016). The Great Recession spurred a reduction in advertising on the radio by more than €200Mn between 2008 and 2014. This has led to questioning of the traditional model of attempting to attract massive audiences and the future model of providing additional services under a new 2.0 scenario full of possibilities.

We note the following consequences of this double business model crisis: "The increase in the competition in the radio sector spurred a dispute regarding space and advertising revenues of local markets and led to a series of mergers and acquisitions carried out by large groups which reduced the diversity of players and availability of programming. This process underpinned a substantial concentration of ownership, audiences and advertising revenues" (Franquet 2008:5). Moreover, this model, highly dependent on licenses granted by governments, seems unable to find highly specialised niche markets but rather has focused on a dynamic of fixed cost cutting and overall decreases in wages in order to adapt to a smaller advertising market.

Like the rest of the media, particularly the press and television, radio stations are having problems adapting to the current situation "of transformation where consumption is personalised, flexibilised and diversified" (Franquet 2011:155) or of "achieving much more segmented marketing that takes advantage of multi-support diffusion possibilities" (Fernández \& Peinado, 2013: 53). Perhaps the problem has to do with the size of market, local management and interactivity with the audience or perhaps with their ability to innovate. The idea isn't so much the circulation of radio programmes via all possible networks and platforms, but rather creating a brand and carrying out programming in accordance with specific niches linked to social network environments prone to participation and the practice of sharing or collaborative economy. Yet, given the expansion of the culture of free access is looks like it is very difficult to innovate in programmes under the "pay to listen" model. Without forgetting about fragmentation of radio audiences, this is a fact that stations must bear in mind in accordance with strategies of advertisers on social networks. 
The radio is transforming. We are no longer facing passive audiences gathered around a receiving device that broadcasts just a few generalist radio stations. Like the case of television, radio audiences have become fragmented and, progressively, radio on demand has become a social reality made possible by technology, and not the reverse. However, this new concept is more complex: "Podcasting not only strengthens the asynchronous, a characteristic that was already offered via à la carte radio services implemented several years ago by a lot of "bitcasters", but rather also adds two highly interesting elements: subscription and mobility" (Gallego, 2012: 134). The magic of live broadcasting is still a key success factor of the radio, but, more and more, we must bear in mind this niche demand for on-demand and à la carte broadcasting.

This is the true revolution of the concept of the radio, so far away from radio waves and so close to Internet protocol today. Yet, among current alternatives there is a simple and cheap innovation that, moreover, is unknown to the general public: digital radio.

Digital radio is a confusing concept that encompasses too many modalities: DTT radio, standard $\mathrm{DAB}+$ radio, Internet radio (streaming or podcasting), and $3 \mathrm{G}$ and $4 \mathrm{G}$ radio; moreover, all of this is available in multiple devices (the radio, television, tablets, computers, DVD players and smartphones). The National Technical Plan for Sound Broadcasting (Royal Decree 802/201) approved the DAB+, but the reality is that this plan is currently in a hibernation state because it is not of interest to anyone, even though it is very efficient in terms of quality and management of the spectrum. It isn't of interest to operators as they prefer to preserve the current comfortable breakdown and distribution of licenses in order to eliminate the possibility of entrance of new competitors and spectators don't buy new receivers because there is no coverage. The only possible solution: switching-off and public radio as the drivers of change.

However, the radio continues to grow: At the beginning of 2012 17\% of Internet users listened to the radio via Internet and preferably in their computer, according to the EGM (http://www.aimc.is/-The-Radio-Tradicional-vs-0nline,196-.html). Clearly, such consumption, in spite of all of its complications, has increased. This 
fact highlights trends in the media sector as a whole: greater personalisation, individualisation, interaction and an à la carte diet. New hyperspecialised audiences in a context of rampant multi-device nomad consumption await the DAB+, which will bring new challenges: new formats, new languages and new ways of "doing radio" in general: a new radio that will co-exist with the old general interest stations.

Future opportunities of operators seem clear: "Once a multiplatform offer strategy has been achieved, what the radio industry will need is to generate sufficient economic returns to maintain the production of contents and adapt to diffusion via different supports... The path laid out by the economic crisis, with respect not only to declining investment but also to divvying up a single budget among all stations, should underpin a tendency to develop new specific offers that respond to increasing fragmentation of audiences and media consumption, as well as new possibilities arising thanks to the creation of social networks" (Martí, Monclús, Gutiérrez \& Ribes 2015: 20).

However, this restructuring isn't easy due to the evolution of the radio concept itself and also to the contradictions inherent in new business models arising from the 2.0 web environment. Furthermore, and in particular we must ask: Is it possible to have an à la carte radio with premium contents with revenues generated only by advertising spending?

\section{Rising digital stars of the media sector}

After surviving the Internet crisis, nobody knew for sure what the consequences would be for the traditional mass media sector. During nearly two decades a lot of dreams came true although many hopes and myths, products of cyber-imagination, are still at the same stage as at the very beginning.

Jo Bardoel argued in 1996 in the European Journal of Communication that it was necessary to go beyond journalism. Even the concept of television had become outdated to explain the "post-network" era. Perhaps it is relevant to bear in mind, as announced by Negroponte, that "The future of television is to stop thinking about television as television" (quoted in Lozt, 2014). 
Gathering of information directly from sources by new channels of communication, giving citizens greater autonomy, the public service crisis vis-à-vis the media (identity, legitimacy and economic crises) and their increasing commercial usage led to the belief that journalism and television were facing a major process of change. The future would belong to the best on-line communities and public debates.

The role of the journalist would no longer be just to gather data but rather to lead debates, public and social. Nicholas Negroponte (1995) pointed out that in the future readers would be able to choose the topics, contents and sources of information that were most appealing to them. If we move slightly less than a decade forward in time we see a major milestone that changed the outlook and expectations: the 2001 crash of the Nasdaq, the market where Internet companies were funded and held accountable.

It began to be apparent, after the initial hype, that online journalism was facing new opportunities and challenges (Bardoel, 2002). Bardoel set forth the idea that social changes were likely to be much slower than technological ones. Society comes before technology, with the crisis of technological determinism. There didn't seem to be any differential value in accessing the news online when a large portion of contents was "shovelware": i.e. unedited contents adapted to the specific requirements of the media channel, thus supporting McLuhan's statement "The Medium is the Message". In other words, many media websites offered the same news in their printed and digital editions. The potential of interactivity and of "hypertextuality", i.e. offering information about the information (Pavlik, 1999), has proved elusive. The "multimediality", that Bardoel defined within the online journalism context as "the convergence of traditional media formats - images (in movement), text, sound - in a story that is told online", hadn't appeared in the media during that first decade. The format was still quite lineal in spite of the potential (Dahlgren, 1996).

Viewings of "The Daily Me" commented previously and developed by Negroponte evolved towards "We, the Media" of Bowman and Willis (2003). The concept of "participative journalism" that aimed to "describe the contents and the objectives 
of online collaboration that is often seen in social and collaborative media" was born. Citizen journalism, as a new alternative media (Atton, 2003) was considered to be a radical change from traditional mass media that depended on three factors (Flew, 2005): distributed contents, collaborative editing and open publication. The citizen journalist was "the person previously known as the audience" (Rosen, 2006), although there were already criticisms concerning the real impact and the difference between publishing and journalism (Lasica, 2003). Some announced its death right from its birth, as it didn't comply with the three E's: ethic, economic and epistemological (Maher, 2005). Problems of objectivity and quality (Grubisich, 2005), as well as legal issues, pointed to their early death.

The appearance of the web Wikileaks, registered in 0ctober 2006, completely changed the former view on this topic. It was a non-governmental organisation (NGO), present in multiple countries, which complied with current legislation in each market but selected those (paradoxically such as Sweden) that protect journalists the most. Thanks to this factor and to its technology it presented itself as a facilitator that eliminated risks faced by sources: they were able to supply, without the risk of being uncovered, confidential data that was later processed and disseminated. In general, information spread was sensitive data for governments and companies. Yet, they claimed that there was a differentiating factor: there was a viable business model, based mainly on donations. The publication in 2010 of a 2007 recording made in Iraq which showed Iraqi journalists under attack by an Apache helicopter, in a video known as "Collateral Murder", marked a before and after in the way collaborative journalism was understood: among other reasons because since 2010 the "Wiki" model was abandoned in favour of a more centralised structure. This initiative gave rise to dozens of similar projects such as 0pen Leaks, created by Daniel Domscheit-Berg after he exited the original project.

Traditional journalism hasn't changed as much as expected in the past decade, not even upon entering the online world. It hasn't fully tapped the potential for creation of communities of readers or users. It's true that legislation such as the LOPD (Spanish Data Protection Act) have led the media to opt to eliminate, edit comments or not accept anonymous profiles, wiping out the potential for creating communities, due to the risk and cost of taking responsibility for audience opinions. 
Another huge problem in recent years has been how to manage the massive quantity of data generated on Internet. In 1970 Alvin Toffler popularised the concept "Information Overload" in his book "Future Shock". This problem is often referred to as "infoxication". This huge quantity of information poses a challenge for the media. According to Cisco in The Visual Networking Index in 2016, global Internet traffic is going to surpass a Zettabyte of information. Therefore, the audience needs help searching (for information): i.e. search engines, keywords and recommendations. Moreover, this is the basis for business models of websites such as Amazon. Curiously, in Spain and a large portion of Europe the traditional media has opted to attack Google from several angles, leading to multiple lawsuits against the giant search engine. In Spain and Belgium lawsuits and the legal framework underpinned Google's decision to shut down its Google News service. This shutdown, and that of other European level news aggregators, led to a drop in traffic and revenues that mainly affected emerging and smaller media players.

At the end of the day, we are talking about competing in an "economy of attention" where "attention is a limited resource - as a person only has so much of it" (Crawford, 2015:11). When all is said and done, before taking action and making a decision we must be conscious (awareness) of the existence of particular contents (Davenport \& Beck, 2001). The on-going increase in data, contents and information implies that the scarce resource in this economy is the attention of users. This also has strategic implications: attracting the attention of a user can cause a barrier of entry to other competitors to be created: as long as his/her attention is focused on a certain set of contents it cannot focus elsewhere. The OECD explains in its 2007 "Policy Brief" that "before a firm can compete in the market, it has to be able to enter it." Therefore, both the attraction of the attention of potential online audiences and the later achievement of customer loyalty (of those users) are essential for the survival of media in this competitive environment.

In addition, Internet has a huge influence on quality and business models: not only due to the huge quantity of contents but also to easy access to them. New independent digital media, mainly bloggers or media such as "The Huffington Post" but also traditional media through their Internet strategies, have focused their business models on generating advertising revenues. The problem is that in that model greater quality or quantity of contents implies greater costs, which do not 
generate greater revenues but rather have the opposite effect. Money is generated by obtaining impressions. Consequently the target is to attract audiences who visit a lot of pages but spend little time within each one. This effect combined with the speed and interactivity of Internet implies that there is little time for checking the rigour and truthfulness of contents. This allows for the design of mechanisms for generating false or self-interested news which regularly end up on the front pages of large digital media (Holiday, 2013). It is even possible that such contents end up appearing in prime time traditional media at a global level if created by Tommaso Debenedetti, who has been successfully spreading false news via Internet and social media for the past decade, including the deaths of the Pope, Fidel Castro and J.K. Rowling.

A media channel must make itself known, normally via search engines or thanks to their brand name but also, sometimes, by paying to advertise itself in other places. Thus, it aims to get people interested in their contents. A percentage of interested parties will end up visiting a page (Homepage or Landing Page, depending on how they find the medium) and - if they find the contents they were looking for or further interest is generated - they may opt to visit additional pages of the same medium. In some cases the user will decide to subscribe and provide their personal data. It is possible that a percentage of them buy a paid subscription to a product or service. Finally, a group of these people will become loyal followers who will recommend the media group. Under this model the main costs are the generation of contents (employees, acquisitions of other contents), distribution (campaigns, special deals) and supporting technology (servers, CMS or Content Management System software, bandwidth). Yet, revenues arise from the generation of impressions: the media player sells traffic reaching its pages to advertisers who insert "banners" and other advertising formats. Why is this incompatible with quality? The time of permanence on a page is relevant: the more time spent looking at a webpage the fewer impressions, i.e. revenues, are generated.

Moreover, expectations of individualisation, and personalisation, of contents and that new projects could turn out to be profitable under these conditions have not been met. It still looks like products are mainly for mass consumption such as information or live broadcasting of sports. The case of the Spanish news aggregator Meneame.net, 
a version of original models such as Digg or Reddit adapted to the local market, is symptomatic. It was founded in 2005 and, although still operating in 2016, its founder Ricardo Galli abandoned the project in 2015 due to, among other reasons, "not knowing how to generate revenues and growth of the business in accordance with the importance of and number of visits received by meneame.net" (Galli, 2015).

Less traditional media also face other challenges. Peter Thiel, technological investor and billionaire, financed Hulk Hogan's lawsuit against Gawker, a well-known network of blogs with the following slogan: "today's gossip is tomorrow's news". The debate regarding the freedom of press and the risk that someone, individual or corporate, can silence a media group by financially drowning it, is on the table.

In any case, we shouldn't forget that what Jeff Zucker said, when he was a NBC executive - "trading analogue dollars for digital pennies" - also applies to the printed media. In the year 2000 The New York Times generated revenues of nearly USD3.5Bn with net profit of close to USD400Mn and employed around 14,000 people. In this era Internet accounted for $1 \%$ of its revenues. Fifteen years later, in 2015, its sales totalled USD1.58Bn generated via subscriptions, advertising and sales; USD638Mn was advertising of which around $30 \%$ was digital with 1,300 employees writing 230 stories. The number of subscribers didn't increase all that much either in spite of the creation of a new App and the support, for marketing it, of Amazon Kindle as well as collaboration with Google in order to achieve faster loading of pages.

The 2013 purchase of the benchmark parent company of traditional journalism, the Washington Post, by a reference player in the new digital arena - Amazon founder Jeff Bezos - created great interest. The digital transition hasn't taken place in accordance with expectations. The Post used 700 people in their "Newsroom" to generate 500 stories per day. How much contents can readers consume? How "glocal" can these stories be: in order to generate interest of small communities and take advantage of Anderson's "Long Tail" effect?

In Spain expectations generated by Internet in the media spurred multimedia groups to make strategic decisions to diversify horizontally and vertically in order to generate synergies and enter global markets that, over time, have proven to be 
unsuccessful. Strategies based on high financial gearing with low interest rates pre-bubble - were implemented in an attempt to ensure dominant positions and guarantee survival, which - in some cases - may be threatened by their current financial situations. Grupo Planeta, Grupo Prisa and Unity Editorial, i.e. some of the top reference players in the sector, are examples of management of expectations which seemed highly visible in the past.

It is true that Internet has allowed for greater access to contents and for a huge quantity of them to be generated, thereby accelerating processes such as training and communication. Yet, it is also true that this quantity of information and access to it implies a situation of nearly "perfect information" (Debreu, 1972) that has underpinned a decline in profit margins in the markets that is affecting many companies (in many markets), with the first and most affected being those companies for which information is their product (De Haro \& Blanco, 2016).

Internet has not had a major impact on free-to-air TV, as it has been seen as a complementary network without the appearance of any true competitors. To the contrary, pay-TV and films financed by generalist television have clearly been affected. The debate regarding free vs. paid services and the segmentation of the audiovisual leisure market in pursuit of greater returns on investment remain relevant (Álvarez-Monzoncillo \& Menor, 2010) and so do topics concerning intellectual property (creative commons, copyright, the so called Mickey Mouse Act, etc.).

Internet as a disruptive technology has destroyed the revenues structures of the past (advertising plus direct payments) that was much more lucrative than the new dominant models (advertising plus subscriptions). Moreover, this is related to the debate regarding the quality of media and the question of whether more can be done with less. The first agents affected by this situation are journalists, screenwriters or creators of contents as they now compete with amateurs, "shovelware" and catalogues of ready-made contents. Moreover, their salaries have increasingly declined and sometimes they are even paid per product. As a result, new media business models still aren't very clear as Internet revenues remain quite small. Another aspect to bear in mind is the transition from offline to online, which is still occurring slowly. It is sufficient to compare the audiences of lineal and non-lineal 


\section{MONOGRÁFICO}

television in order to understand this slow process of change and the strength of live television. We are facing a scenario of digital media, but with "fundamental changes in the information and entertainment that people need, how and when they use it, and how it is financed" (Picard, 2014: 195).

For hardware companies "contents was the king", but those who have truly made money have been telecommunications companies supplying Internet access to companies and users. In other words, "connectivity has been the queen". This is demonstrated by vertical integration of entertainment groups and telecommunications companies. We come to one main conclusion from this new change: "The technological wonders and the dazzling entrance of online television appear to be clearly contradicted by the reality of small audiences and revenues, and the economic persistence of standard television" (Sherman and Waterman, 2014: 275).

However, OTT services, the expansion of MCN, the potential of Internet, UGC activities, Millenials' new usages and customs, and the inevitable digital migration should underpin a new panorama with survival of aspects of mass media typical of the 20th century together with differentiating and relevant aspects of the new media of the 21st century. This change should create opportunities for new companies and industries, reconfiguring the media scenario as has traditionally and historically occurred when it has faced disruptive changes.

\section{Conclusions}

The digital economy is here to stay. Mass media seems to be collapsing, little by little, as it is unable to find its place under a new more complex scenario. New business models haven't consolidated yet. The mass media-mass society binomial is mutating on the back of globalisation and fragmentation of audiences. Consumption is gradually becoming personalised and individualised. Society is suffering a "breakdown" with the arrival of digital gaps and with the alleged freedom to choose from all that exists in the giant warehouse of products (news, reports, programmes, films, etc.) which may be accessed via the Internet. A new inter-domestic system is under configuration: more concentrated, less diverse, plural and multilateral. And, perhaps, it is still too soon to consider this process completed. 
However, the media is still managing to hold-up: watching their own "vanity" burn up whilst attempting to halt the disruption caused by the Internet. The media continues to resist: radio and television audiences are being maintained as if nothing had happened and the press market is gradually segmenting, as always, in accordance with the cultural and economic levels of their readers. Public intervention is disoriented, not knowing how to reconfigure the former balances of public media services under the weight of its own contradictions: public vs. private, concentration vs pluralism, homogeneity vs. diversity, and/or halting vs. encouraging change.

In fifteen years the Internet has transformed the competitive panorama: not necessarily improving either the competition or the competitors. The media are dependent not only on supply but rather also on demand. Consumption of media is closely related to the competition of audiences and readers. Rising access to the Internet hasn't necessarily implied an increasing access to (or equality in terms of) knowledge and culture.

The trend towards individualisation and personalisation of consumption of mass media as one of the keys to globalisation due to the impact of the Internet appears to have stalled. Moreover, mass and mainstream products - as we know them - will survive for a long time. In spite of the Internet, media remain fiercely local: with adjustments of North American products still needed.

The financial impact of the crisis of the dot-com bubble burst has had a huge influence on the media sector that isn't often commented. Access to cheap financing and promises of a new, cheaper, channel with increasing penetration rates and bidirectional access - i.e. the Internet - generated expectations that were dramatically confronted with a different reality following the arrival of the Great Recession. Neither are new business models really all that new, nor have paradigms redefined the media, nor has the new digital economy generated more value for the media industry. In fact, the truth is quite the opposite.

Yet, undeniably, users and consumers have gained some differential value in this process: access to a greater quantity of contents at a low cost, ubiquity, and the possibility of sharing, commenting and/or co-creating in a quick and simple way. 
40 | José María Álvarez-Monzoncillo, Guillermo de Haro Rodríguez y Javier López-Villanueva

\section{MONOGRÁFICO}

However, the industry is still in the midst of a stabilisation process. Like in any other war, the first victim is the truth and in this case the second casualty has been quality. However, in this complex process of converging markets and bonfires perhaps operators and users should bear in mind the saying "Vanity of vanities, all is vanity".

\section{Notes}

[1] General Mass Media Survey, from April 2015 to March 2016.

\section{References}

AEDE (2015). Libro blanco de la prensa 2015. Madrid: Asociación de Editores de Diarios Españoles.

Álvarez-Monzoncillo, J. M. \& Menor, J. (2010). La televisión, entre la gratuidad y el pago. Telos, 85, 36-44.

Álvarez-Monzoncillo, J. M., Baraybar-Fernández, A., \& López-Villanueva, J. (2015).

Audiovisual Production in Spain: Fewer Resources, Same Problems, New challenges. Economia della Cultura, 25(2), 211-222.

APM (2015). Informe Annual de la Profesión Periodística 2015. Madrid: Asociación de la Prensa de Madrid.

Artero, J.P., Orive, V. \& Latorre, P. (2015). Efficiency and benchmarks of regional public service broadcasters in Spain. Communication \& Society, 28 (3), 13-28.

Artero, J. P., \& Sánchez-Tabernero, A. (2015). Media and telecommunications concentration in Spain (1984-2012). European Journal of Communication, 30(3), 319-336.

Atton, C. (2003). What is "alternative journalism"? Journalism: Theory, Practice and Criticism, 4 (3), 267-400.

Badillo, A. \& Pérez, M. (2012). Estructura del mercado radiofónico español. Transformaciones y tendencias del clivaje público/privado. In I. Gallego \& T. García (Eds.), Sintonizando el futuro: Radio y producción sonora en el siglo XXI (pp.61-104). Madrid: IORTV.

Bakker, G. (2005). The Decline and Fall of the European Film Industry: Sunk Costs, Market Size, and Market Structure. Economic History Review, 58 (2), 310-351. 
Bardoel, J.L.H. (1996). Beyond journalism: a profession between information society and civil society. European Journal of Communication, 11 (3), 283-302. Bardoel, J.L.H. (2002). The Internet, journalism and public communication policies. International Communication Gazette, 64 (5), 501-511.

Bowman, S., \& Willis, C. (2003). We Media: How Audiences are Shaping the Future of News and Information. In J.D. Lasica (Ed.), The Media Center at the American Press Institute (Julio 2003, Ed.). Recuperado de http://www.hypergene.net/ wemedia/download/we_media.pdf

Bresinger, J., Gullan, R., \& Chakars, J. (2014). The News Media and New Media: The Internet's Effect on Civic Engagement. Media Psychology Review, 8 (1).

Bruns, A. (2005). Gatewatching: Collaborative Online News Production. New York: Peter Lang.

Casero-Ripollés, A. (2010). Prensa en Internet: nuevos modelos de negocio en el escenario de la convergencia. El profesional de la información, 16, 595-601.

Caves, R.E. (2000). Creative Industries: Contracts between Art and Commerce. Boston: Harvard University Press.

Conboy, M., \& Steel, J. (2008). The Future of Newspapers. Journalism Studies, 9 (5), 650-661.

Crawford, M. B. (2015). The World Beyond Your Head: On Becoming an Individual in an Age of Distraction. New York: Farrar, Straus and Giroux

Dahlgren, P. (1996). Media Logic in Cyberspace: Repositioning Journalism and its Publics. Javnost-The Public, 3 (3), 59-73.

Davenport, T. H., \& Beck, J. C. (2001). The Attention Economy: Understanding the New Currency of Business. Boston: Harvard Business School Press.

Debreu, G. (1972). Theory of Value: An Axiomatic Analysis of Economic Equilibrium. New Haven, CT: Yale University Press.

De Haro, G., \& Blanco, L. (2016). El espectador económico. Madrid: Hispalibros.

Díaz-Nosty, B. (2011). La crisis en la industria de la prensa: Vida más allá del papel. Telos, 86, 52-65.

Díaz-Nosty, B. (2013). La prensa en el nuevo ecosistema informativo: “QQue paren las rotativas!". Madrid: Ariel/Fundación Telefónica.

Dicken, P. (2011). Global Shift. London: SAGE.

Dolfsma, W., \& Nahuis, R. (2006). Media \& Economics: Uneasy Bedfellows? De Economist, 154 (1), 107-124. 
42 | José María Álvarez-Monzoncillo, Guillermo de Haro Rodríguez y Javier López-Villanueva

\section{MONOGRÁFICO}

Evans, D.S., \& Schmalensee, R. (2016). Matchmakers: The New Economics of Multisided Platforms. Boston: Harvard Business Review Press.

Fernández, M., \& Peinado, M. (2013). La empresa radiofónica actual. In I. Gallego

\& T. García (Eds.), Sintonizando el futuro: Radio y producción sonora en el siglo XXI (pp. 29-60). Madrid: IORTV.

Flew, T. (2005). New media: An introduction. New York: 0xford University Press.

Franquet, R. (2008). Radio digital en España: incertidumbres tecnológicas y amenazas al pluralismo. Laboratorio de Alternativas, Working Paper 132/2008. Retrieved from https://www.falternativas.org/ content/download/11344/350921/ le/Doc132.pdf.

Franquet, R. (2011). La radio y la red: Nuevas opciones y desafios cardinales. In E. Bustamante (Ed.) Las industrias culturales audiovisuales e Internet (pp. 133156). Tenerife: Ideco.

Gallego, J. L. (2012). Relaciones entre podcasting, radio y movilidad: la distribución de contenidos de audio. Telos, 92, 127-135.

Galli, R. (2016, 1 de Febrero). Una nueva etapa para Meneame. Meneame.net. Recuperado de https://blog.meneame.net/2016/02/01/una-nueva-etapa-para-meneame/.

García-Avilés, J. A. (2010). "Citizen journalism" in European television websites: lights and shadows of user generated content. Observatorio $\left(O B S^{*}\right), 4(4)$, 251.263.

García-Santamaría, J.V. (2016). Los grupos multimedia españoles. Análisis y estrategias. Barcelona: Editorial UOC.

García-Santamaría, J. V., Pérez-Serrano, M. J., \& Maestro-Espínola, L. (2016). Los clubs de suscriptores como nuevo modelo de financiación de la prensa española. El profesional de la información, 25(3), 395-403.

Geels, F.W. (2014). Reconceptualising the Co-evolution of Firms-in-industries and their Environments: Developing an inter-disciplinary Triple Embeddedness Framework. Research Policy, 43 (2), 262-277.

Gereffi, G. (1994). The Organization of Buyer-Driven Global Commodity Chains. In G. Gereffi \& M. Korzeniewicz (Eds.), Commodity Chains and Global Capitalism. Wetsport: Praeger.

Goldin, I. \& Kutarna, C. (2016). Age of Discovery: Navigating the Risks and Rewards of Our New Renaissance. London: Bloomsbury.

Goyanes, M. (2012). Estrategias de pago por contenidos de la prensa digital: Una aproximación teórica. index. comunicación, 2(1), 91-112. 
Goyanes, M. (2014). An Empirical Study of Factors that Influence the Willingness to Pay for Online News. Journalism Practice, 8 (6), 742-757.

Granovetter, M. (1985). Economic Action and Social Structure: The Problem of Embeddedness. American Journal of Sociology, 91 (3), 481-510.

Graybeal, G., \& Hayes, J.L. (2011). A Modified News Micropayment Model for Newspapers on the Social Web. International Journal on Media Management, 13 (2): 129-148.

Grubisich, T. (2005). Grassroots journalism: Actual content vs. shining ideal. Online Journalism Review, 6, 148.

Guerrero, E., Diego, P., \& Pardo, A. (2013). Distributing audiovisual contents in the new digital scenario: Multiplatform strategies of the main Spanish TV networks. In M. Friedrichsen \& W. Mülh-Benninghaus (Eds.) Handbook of social media management (pp. 349-373). Berlin: Springer.

Heinonen, A. \& Luostarinen, H. (2008). Reconsidering 'journalism' for journalism Research. In M. Löffelholz \& D. Weaver (Eds.) Global Journalism Research. Theories, Methods, Findings, Future. Hoboken: Wiley, 227-239.

Holiday, R. (2013). Trust me, I'm lying: Confessions of a Media Manipulator. New York: Penguin/Portfolio.

Hopkins, T.K. \& Wallerstein, I. (1986). Commodity Chains in the World-Economy prior to $1800 "$. Review, 10 (1), 157-170.

Kaplinsky, R. (2013). Global Value Chains, Where they Came From, Where they Are Going and Why this Is Important. IKD Working Paper, 68.

Kogut, B. (1984). Normative Observations on the International Value-Added Chain and Strategic Groups. Journal of International Business Studies, 15 (2), 151-167. Lasica, J. D. (2003). What is participatory journalism. Online Journalism Review, 7 (08), 2003.

López Villanueva, J. (2011). La reconfiguración de la cadena de valor. In J.M. Álvarez Monzoncillo (Coord.), La televisión etiquetada: Nuevas audiencias, nuevos negocios (pp. 9-31). Madrid: Ariel/Fundación Telefónica.

Lotz, A. (2014). The television will be Revolutionized. New York: New York University Press.

Maher, V. (2005). Citizen journalism is dead. Media in Transition, New Media Lab, Rhodes University. 
44 | José María Álvarez-Monzoncillo, Guillermo de Haro Rodríguez y Javier López-Villanueva

\section{MONOGRÁFICO}

Martí, J.M., Monclús, B., Gutiérrez, M., \& Ribes, X. (2014). La radio, modelo de negocio en transición: Estrategias de oferta y de comercialización en el contexto digital. Quaderns del CAC, 41, Vol. XVIII, 13-22.

McLuhan, M. (1964). Understanding Media. New York: McGraw-Hill.

MECD (2016). Anuario de Estadísticas Culturales 2015. Madrid: Ministerio de Educación, Cultura y Deporte.

Meyer, P. (2009). The vanishing newspaper: Saving Journalism in the Information Age. Columbia: University of Missouri Press.

Missika, J. L. (2006). La Fin de la Télévision. Paris: Seuil.

Morvan, Y. (1991). Fondements d'Économie Industrielle. Paris: Economica.

Negroponte, N. (1995). Being Digital. New York: Alfred A. Knopf.

OECD (2005). Competition and Barriers to Entry (s.f.). En Policy Brief, Public Affairs Division

at OECD. Recuperado de http://www.oecd.org/competition/mergers/37921908.pdf

OECD (2010). The Evolution of News and the Internet. Paris: OECD.

Osterhammel, J., \& Peterson, N.P. (2013). Globalization: A Short History, Princenton:

Princeton University Press.

Pavlik, J. V. (1999). New Media and News: Implications for the Future of Journalism.

New Media and Society, 1 (1), 54-59.

Picard, R.G. (2005). Unique Characteristics and Business Dynamics of Media Products. Journal of Media Business Studies, 2 (2), 61-69.

Picard, R.G. (2008). Shifts in Newspaper Advertising Expenditures and Their Implications for the Future of Newspapers. Journalism Studies, 9(5), 704-716.

Picard, R.G. (2014). Digital Media and the Roots of Marketing Strategies. En Y. Liu \& R.G. Picard, Policy and Marketing Strategies for Digital Media (pp. 195-201). London: Routledge.

Porter, M. (1985). Competitive Advantage: Creating and Sustaining Superior Performance. New York: Free Press.

Quintas-Froufe, N. \& González Neira, A. (2016). Consumo televisivo y su medición en España: Camino hacia las audiencias híbridas. El profesional de la información, 25 (3), 376-383.

Rosen, J. (2006). The People Formerly Known as the Audience, PressThink, 27 June. Rothman, W. \& Koch, J. (2014). Creativity in strategic lock-ins: The newspaper industry and the digital revolution. Technological Forecasting \& Social Change, 83, 66-83. 
Sharp, B. (2010). How Brands Grow: What Marketers Don't Know. 0xford: Oxford University Press.

Sherman, R., \& Waterman, D. (2014). Technology and Competition in U.S. Television. En Y. Liu \& R.G. Picard, Policy and Marketing Strategies for Digital Media (pp. 265-279). London: Routledge.

Sturgeon, T.J. (2008). Mapping Integrative Trade: Conceptualising and Measuring Global Value Chains. International Journal of Technological Learning, Innovation and Development, 1 (3), 237-257.

Telefónica (2016). La Sociedad de la Información en España 2015. Madrid: Ariel/ Fundación Telefónica.

The Cisco Visual Networking Index. En Cisco.com. Recuperado de http://www. cisco.com/c/en/us/solutions/service-provider/visual-networking-index-vni/ index.html

2001 Annual Report \& Form 10-K. En The New York Times Company. Recuperado de http:// s1.q4cdn.com/156149269/files/doc_financials/annual/2000_Annual_Report.pdf

2015 Annual Report \& Form 10-K. En The New York Times Company. Retrieved from http://s1.q4cdn.com/156149269/files/doc_financials/annual/2015/Bookmarked2015-Annual-Report.pdf.

Twenge, J.M. \& Campbell, W.K. (2009). The Narcisism Epidemic: Living in the Age of Entitlement. New York: Free Press.

Uricchio, W. (2009). Contextualizing the Broadcast Era: Nation, Commerce and Constraint. Annals of the American Academy of Political and Social Science, 625 (1), 60-73.

Van Dijk, M., Nahuis, R. \& Waagmeester, D. (2006). Does Public Broadcasting Serve the Public? The Future of Television in the Changing Media Landscape. De Economist, 154 (2), 251-276.

Winston, B. (1998). Media Technology and Society. London: Rotledge.

Wolk, A. (2015). Over the Top: How the Internet is (Slowly but Surely) Changing the Television Industry. New York: CreateSpace Independent Publishing Platform.

WFA (2016). Compendium of Ad Fraud Knowledge for Media Investors. Brussels: World Federation of Advertisers.

Zucker, J. (2013). Conference "CNN's Jeff Zucker: Digital is our future". Fortune Brainstorm Tech Conference. Recuperado de https://www.youtube.com/ watch?v=Vnx7gZtUUbU 